\title{
Go local, European review of electronic health records advises
}

$\mathrm{G}$ randiose nationwide electronic health record (EHR) systems aimed at aggregating patient data into general summaries may not be feasible, necessary or medically justified, according to a European Commission report.

The review of European ehealth investments suggests that decentralized approaches are preferable. Largescale systems are "much more difficult than you ever dreamt of," says Karl Stroetmann, lead author of the stocktaking survey (www.ehealth-strategies .eu/report/eHealth_Strategies_Final _Report_Web.pdf).

"It takes much more time and it takes much more money than was expected," Stroetmann adds. "We found everywhere that local efforts work better than national efforts. And that's because healthcare itself is mostly local."

The report, European countries on their journey towards national ehealth infrastructures, helps put Canada's ehealth quandary into perspective, says Dr. Robyn Tamblyn, professor of medicine McGill University in Montréal, Quebec, scientific director of the Canadian Institutes of Health Research's Institute of Health Services and Policy Research, and member of McGill's Clinical and Health Informatics Research Group. Tamblyn's group has found that Canada Health Infoway's efforts to build a complex nationwide health "infostructure" emphasized national over regional investment, while failing to link the implementation of ehealth technologies to strategic health objectives such as "improvements in patient safety, management of chronic diseases and sustainability of the health care system" (www.cmaj.ca /cgi/doi/10.1503/cmaj.100856).

The European report reinforces arguments that Canada needs to retreat from an ehealth approach driven by bureaucrats and software executives. "The best way to build these systems is to let doctors and other healthcare professionals drive the entire process,"

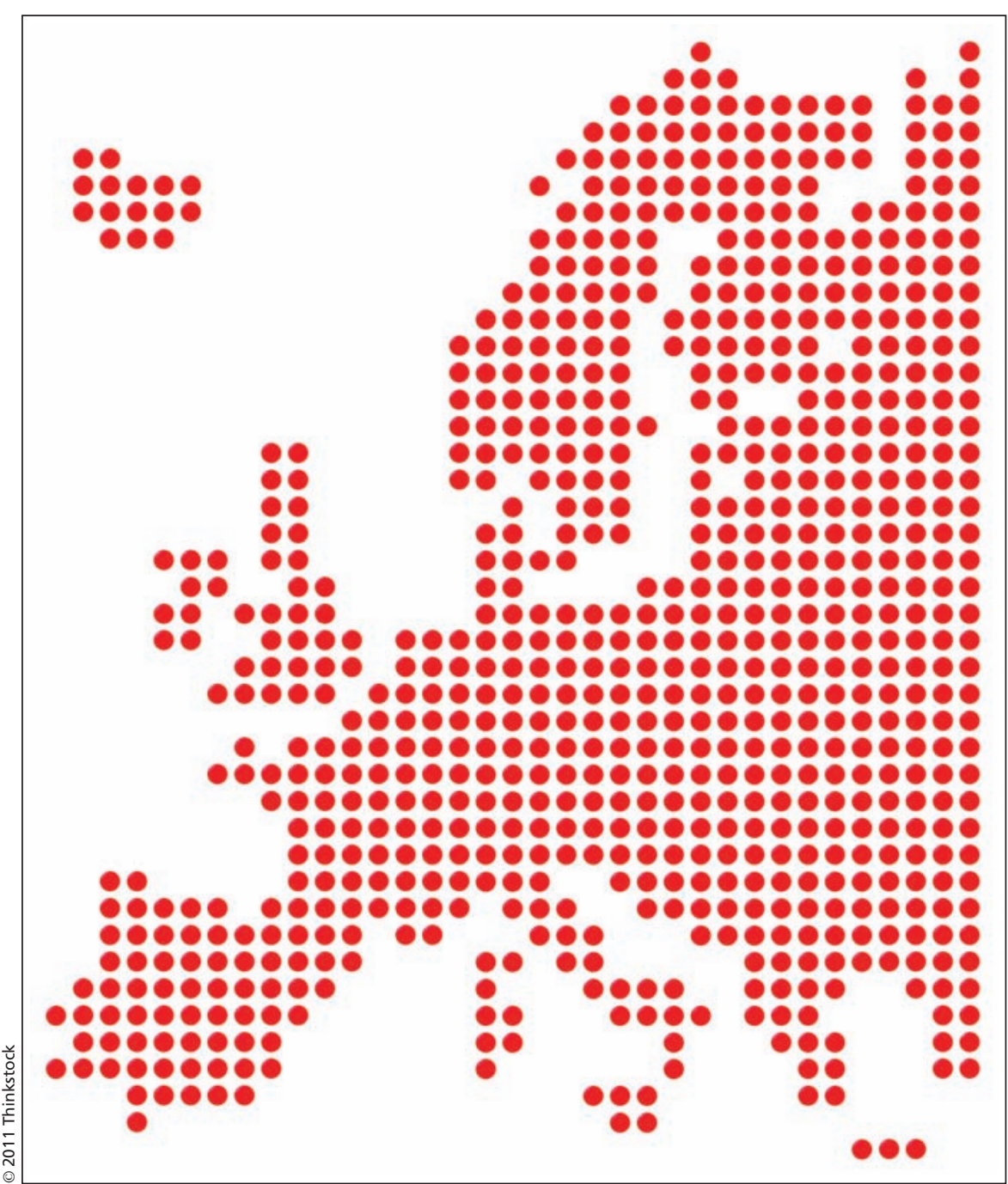

Europe has largely ditched plans to develop broad-scale ehealth systems, like the one sought by Canada Health Infoway, in favour of smaller scale, regional systems, according to a European Commission report.

says Stroetmann, citing Scotland as a case where an advanced system was inexpensively crafted by physicians.

Stroetmann says Europe leads the world in constructing smaller scale, regional ehealth systems rather than national scale ones like that sought by Canada Health Infoway. Only Spain's Andulacia province has achieved a broader scale system and is "well on its way to becoming the first true regional EHR system for a significant sized population (over 8 million) fully integrating all patient information from pri- mary to tertiary care including emergency and in-patient care, also connecting all pharmacies, their logistics and billing," the report states.

Large, national systems are not yet feasible beyond a certain level, the report adds. "It seems that the complexity of national EHR systems cannot be managed in larger countries. European experience so far suggests that countries with more than around $10 \mathrm{~m}$ [million] inhabitants tend to fail with their endeavours, particularly if they do not feature a top-down healthcare system. 
It is also increasingly evident that clinicians' enthusiasm for comprehensive electronic health records, which may connect patient data in diverse record systems, relates primarily to perceived benefits in their immediate surroundings. This would suggest a middle-out approach, opting for local and regional systems building on a national infrastructure. Seamless national exchange of core patient data like summaries could be assured via common data models."

Stroetmann says Europe is increasingly looking to focus its efforts on an interoperable, inter-regional system, known as Smart Open Services for European Patients, that aspires to the more limited objective of connecting 12 nations to a secure database sharing only basic patient summaries and prescription records.

It only has a budget of about $\$ 30$ million but "sometimes, too much money is not enough of a solution," Frank Linden, the project's director said during a presentation in Vancouver, British Columbia in June 2010.

The report notes that the clinical need for large-scale national systems "is being questioned more and more" and that clinical enthusiasm for such systems is waning. It also urges external, independent oversight of ehealth strategies and investments, which Canada lacks (www.cmaj.ca/cgi/doi/10.1503/cmaj.109 -3783).

The need for external assessment is self-evident when vast sums of money are handed to ehealth bureaucrats, with minimal oversight and minimal opportunity for dialogue about goals and priorities, says Trisha Greenhalgh, director of the Healthcare Innovation and Policy Unit at Barts and the London School of Medicine and Dentistry, Queen Mary University of London in England.

Policy-makers need to be more skeptical of demands for ehealth monies made by bureaucrats and industry, adds Aziz Sheikh, professor of pri- mary care research and development at the University of Edinburgh in Scotland. Many governments see ehealth investments as "the answer" without regard to the lack of evidence supporting the value of ehealth technologies, many of which remain primitive and require "working out," Sheikh says. "It doesn't really fit in with what politicians hoped."

Trevor Hodge, senior vice president for investment strategy and alliances at Canada Health Infoway, noted in a blog (http://infowayconnects.infoway-info route.ca/blog/global-perspectives/268 -progress-report-european-e-health-ini tiatives/\#axzz1KqQ6yIRO) about the European report that "while many European countries are planning to implement EHR or patient summary systems, so far only a few countries have patient summary or limited, EHR-like services operational at the national level." — Paul Christopher Webster, Toronto, Ont.

CMAJ 2011. DOI:10.1503/cmaj.109-3861

Editor's note: Nineteenth in a series on electronic health records:

Part I: Canada's electronic health records initiative stalled by federal funding freeze (www.cmaj.ca/cgi/doi/10.1503/cmaj.109-3183)

Part II: Ontario's plan for electronic health records is at risk, official says (www.cmaj.ca/cgi/doi/10.1503/cmaj.109-3193)

Part III: Electronic health records a "strong priority" for US government (www.cmaj.ca/cgi/doi/10.1503/cmaj.109-3218)

Part IV: The pocketbook impact of electronic health records: Part 1 (www.cmaj.ca/cgi/doi/10.1503/cmaj.109-3225)

Part V: The pocketbook impact of electronic health records: Part 2 (www.cmaj.ca/cgi/doi/10.1503/cmaj.109-3226)

Part VI: National standards for electronic health records remain remote (www.cmaj.ca/cgi/doi/10.1503/cmaj.109-3239)

Part VII: National electronic health records initiative remains muddled, auditors say (www.cmaj.ca/cgi/doi/10.1503/cmaj.109-3242)

Part VIII: New electronic health record blueprint to call for increased patient participation (www.cmaj.ca/cgi/doi/10.1503/cmaj.109-3265)

Part IX: Albertans to gain electronic access to personal health files (www.cmaj.ca/cgi/doi/10.1503/cmaj.109-3270)

Part X: Canadian hospitals make uneven strides in utilization of electronic health records (www.cmaj.ca/cgi/doi/10.1503/cmaj.109-3288)

Part XI: United States to compel physicians to make "meaningful use" of electronic health records (www.cmaj.ca/cgi/doi/10.1503/cmaj.109-3361)

Part XII: Canada's ehealth software "Tower of Babel" (www.cmaj.ca/cgi/doi/10.1503/cmaj.109-3717)

Part XIII: National electronic health information strategy needs to be refocused, critics say (www.cmaj.ca/cgi/doi/10.1503/cmaj.109-3744)

Part XIV: Seeing is Belizing (www.cmaj.ca/cgi/doi/10.1503/cmaj.109-3782)

Part XV: Experts call for health infoway “watchdog” (www.cmaj.ca/cgi/doi/10.1503/cmaj.109-3783)

Part XVI: Infoway tacks towards “networked” patients (www.cmaj.ca/cgi/doi/10.1503/cmaj.109-3798)

Part XVII: Medical data debates: Big is better? Small is beautiful? (www.cmaj.ca/cgi/doi/10.1503/cmaj.109-3799)

Part XVIII: External performance audit concludes Canada Health Infoway missed program targets (www.cmaj.ca/cgi/doi/10.1503/cmaj.109-3860) 